WellBeing International

WBI Studies Repository

2010

\title{
Behavior of a Solitary Sociable Female Bottlenose Dolphin (Tursiops truncatus) off the Coast of Kent, Southeast England
}

\author{
Sonja Eisfeld \\ Whale and Dolphin Conservation Society \\ Mark P. Simmonds \\ Whale and Dolphin Conservation Society \\ Laura R. Stansfield \\ Whale and Dolphin Conservation Society
}

Follow this and additional works at: https://www.wellbeingintlstudiesrepository.org/acwp_ena

Part of the Animal Studies Commons, Behavior and Ethology Commons, and the Comparative Psychology Commons

\section{Recommended Citation}

Eisfeld, S. M., Simmonds, M. P., \& Stansfield, L. R. (2010). Behavior of a Solitary Sociable Female Bottlenose Dolphin (Tursiops truncatus) off the Coast of Kent, Southeast England. Journal of Applied Animal Welfare Science, 13(1), 31-45.

This material is brought to you for free and open access by WellBeing International. It has been accepted for inclusion by an authorized administrator of the WBI Studies Repository. For more information, please contact wbisr-info@wellbeingintl.org.

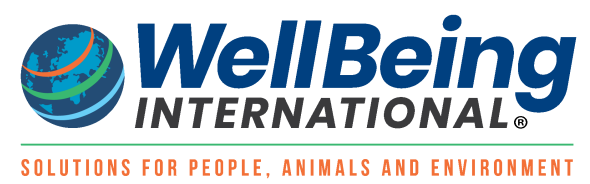




\title{
Behavior of a Solitary Sociable Female Bottlenose Dolphin (Tursiops truncatus) off the Coast of Kent, Southeast England
}

\author{
Sonja M. Eisfeld, Mark P. Simmonds, and Laura R. Stansfield \\ The Whale and Dolphin Conservation Society (WDCS)
}

\begin{abstract}
$\underline{\text { ABSTRACT }}$
This article provides a report of the behavior of a solitary sociable dolphin studied on the southeast coast of England in 2007. This is the first study of its kind in which behavior of such a nonhuman animal was systematically studied. By the time of this study, this young female was highly interactive with people in the water. People accompanied the dolphin for $18.4 \%$ of the $100 \mathrm{hr}$ of observation, and their presence changed her behavior. The study recorded 39 different behaviors; feeding and resting behaviors declined in frequency in the presence of people. In addition, the dolphin exhibited behavior possibly hazardous to people in the water, which included preventing swimmers from leaving the water. The dolphin received several wounds, at least one of which was life-threatening. This article discusses the welfare implications for such animals.
\end{abstract}

Dolphins are gregarious mammals, and most behavioral studies focus on aspects of their social affiliation and group composition (Connor, Wells, Mann, \& Read, 2000; Lusseau et al., 2003; Smolker, Richards, Connor, \& Pepper, 1992; Würsig \& Würsig, 1977). However, there exists literature describing the behavior of individuals who seem to spend most, or even all, their time without conspecifics (Bearzi, 1997; Lockyer, 1978; Lockyer \&Morris, 1986) and (in some instances at least) seeking instead the company of humans (Lockyer, 1990). These particular nonhuman animals spend long periods of time in shallow waters facilitating encounters with people who swim with them or touch them. Various authors have published evidence that this kind of behavior is learned and develops over a period of time as a result of interactions with people (Frohoff, 2000; Frohoff \& Packard, 1995; Knight \& Temple, 1995; Simmonds \& Stansfield, 2007; Wilke, Bossley, \& Doak, 2005).

Wilke et al. (2005) identified four stages of evolution from a solitary, nonhuman-habituated dolphin to a highly interactive human-habituated, "solitary sociable" dolphin. In Stage 1, the dolphin first appears and remains in a new home range that is sometimes a very small (often less than $1 \mathrm{~km} 2$ ) and restricted area. The dolphin may follow boats (in most cases fishing boats) or inspect fishing gear but does not yet approach humans. 
In Stage 2, the dolphin may regularly follow boats. Locals become aware of the dolphin's presence and attempt to swim alongside. The dolphin appears curious but stays some distance from the swimmers.

In Stage 3, the dolphin becomes familiar with the presence of a limited number of people who may have deliberately attempted to habituate the mammal. Interactions may include swimming in close proximity or diving side by side, and the dolphin now allows touching and allows the dorsal fin to be held for swimmers to be pulled along.

In Stage 4, the presence of the dolphin becomes widely known, often assisted by significant media exposure. Visitors from outside the local area come to see and swim with the dolphin, who soon becomes a major tourist attraction. Inappropriate human behavior may provoke unwanted and even dangerous behavior in the dolphin, including dominant, aggressive, and sexual behaviors directed at humans.

A workshop on solitary sociable cetaceans was held in San Diego to coincide with the meeting of the 16th Biennial Conference of the Society for Marine Mammalogy there in 2005 (Frohoff, Vail, \& Bossley, 2006). This workshop, which brought together experts from all over the world, concluded that solitary sociable cetaceans seemed to be a growing phenomenon worldwide and called for more research. Besides solitary bottlenose dolphins (Tursiops truncatus and Tursiops aduncus), there have been reports of the following:

1. Solitary belugas (Delphinapterus leucas; Goodwin \& Dodds, 2008; Hartley et al., 2005; Kinsman \& Frohoff, 2005),

2. Orcas (Orcinus orca; Chisholm, 2005; Goodwin \& Dodds, 2008; Sandstrom, 2005),

3. Risso's dolphin (Grampus griseus; Goodwin \& Dodds, 2008),

4. Spotted dolphins (Stenella attenuata; Goodwin \& Dodds, 2008),

5. Common dolphins (Delphinus delphis; Goodwin \& Dodds, 2008),

6. Dusky dolphins (Lagenorhynchus obscurus; Goodwin \& Dodds, 2008),

7. A narwhale (Monodon monocerus; Goodwin \& Dodds, 2008), and

8. A tucuxi (Sotalia fluviatilis; Goodwin \& Dodds, 2008).

The United Kingdom has recently hosted several such animals, all bottlenose dolphins. This article looks in detail at the behavior of one. The animal in question was known to be solitary from April 2006 to October 2007 and seen to progress through the stages described by Wilke et al. (2005) and Simmonds and Stansfield (2007). This study details her behavior at Stage 4, shortly before she disappeared from the UK coast.

\section{METHOD}

\section{Study Animal}

The dolphin known as Dave was a small (approximately $2 \mathrm{~m}$ long and probably subadult), female, bottlenose dolphin (Figure 1[a]) observed in the waters around Folkestone, Kent, in Southeast England (Figure 2). Dave had distinguishing white patches on both sides of her dorsal fin and some minor nicks in her trailing edge that were convenient means of identification. Bottlenose dolphins are rare in this region, and she was not known to associate with any conspecifics (A. Levine \& T. Whittaker, personal communication, August 23, 2007). When Dave first appeared in April 2006, she appeared to be scarred, possibly from entanglement in a net, but otherwise healthy ( $T$. Whittaker, personal communication, August 23, 2007). In October 2007, she suffered a severe injury to her tail, losing half her fluke (Figure $1[c]$ ), and two deep wounds to the leading edge of her dorsal fin (Figure 1[b]). All were probably due to entanglement in monofilament fishing line used by anglers on the beach; however, the tail wound might have resulted from a propeller strike (noting that she had other recent wounds caused by propellers). 
FIGURE 1 Dave in her prime (a) and after being severely injured by fishing line (b, c) (Photos courtesy of Terry Whittaker).

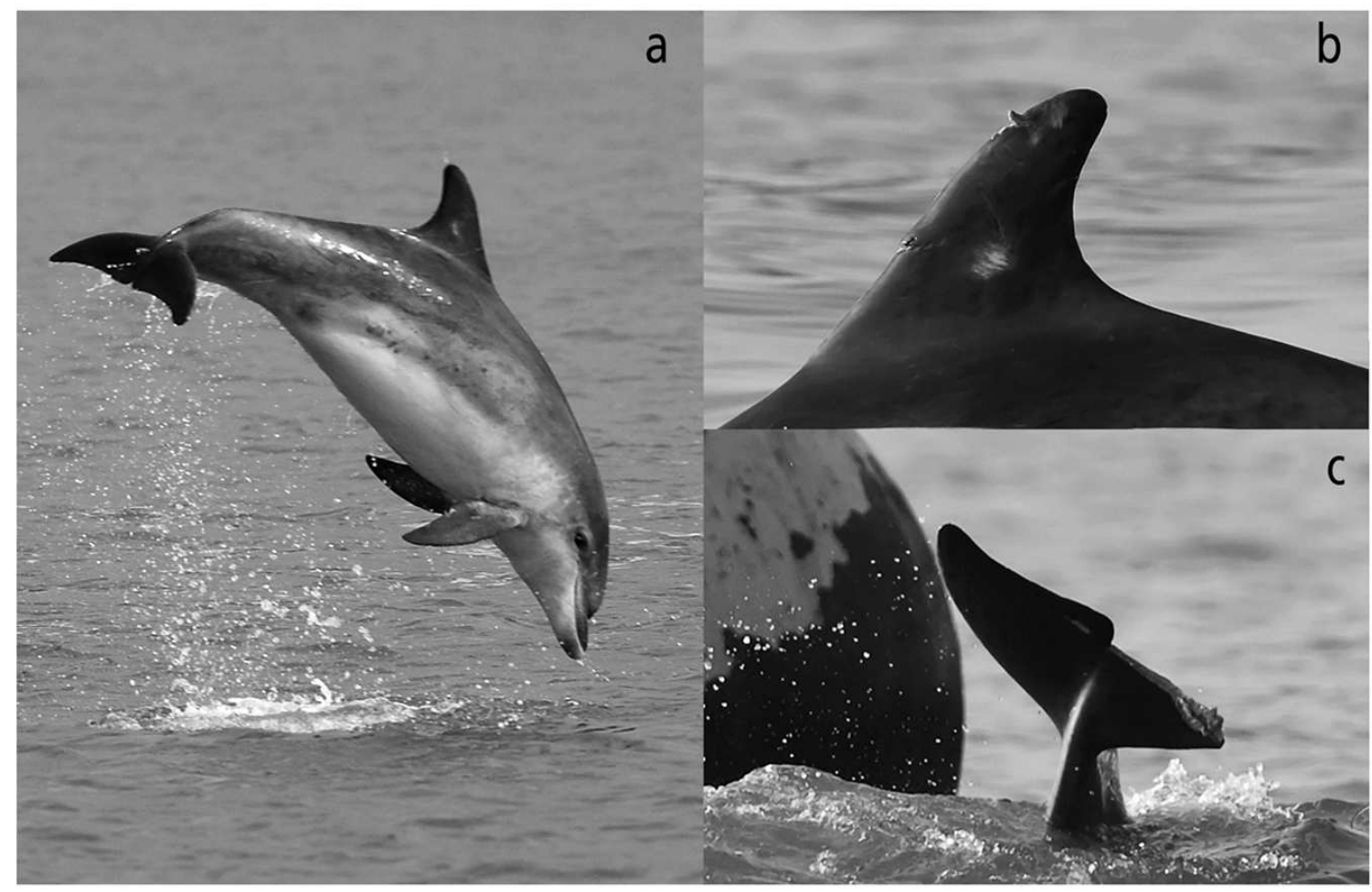

FIGURE 2 Location of the study area, Folkestone, Kent, southeast England and indication of Dave's home range.

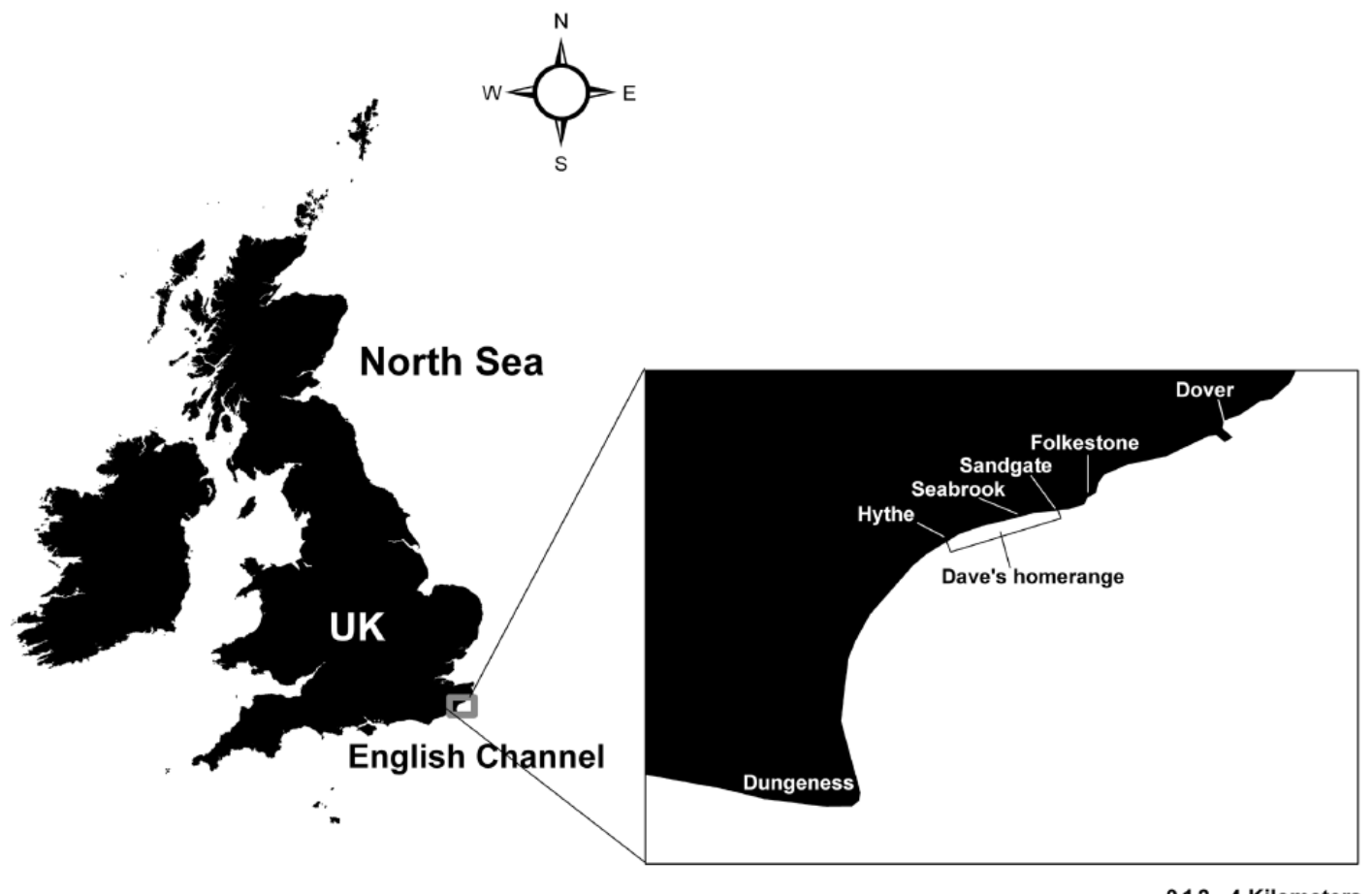

0124 Kilometers 


\section{Study Site}

Dave's home range was in the waters of the English Channel on the coast of Kent between Sandgate and Hythe, a distance of approximately $5.0 \mathrm{~km}$ (Figure 2), and she favored five different areas in particular, from east to west: (a) Sandgate, (b) Battery Point in Seabrook, (c) Hythe Imperial Hotel, (d) Hythe Sailing Club, and (e) Hythe Fishermen's Beach. All areas are comprised of limestone pebble beaches that slope steeply down to a mainly sandy seabed. Battery Point features a reef. Battery Point and Hythe Imperial Hotel feature offshore markers (buoys) approximately $180 \mathrm{~m}$ from the beach at high tide.

Rarely swimming farther offshore than $500 \mathrm{~m}$ and mostly staying within the offshore markers, Dave could be approached from the beach or by boat by people seeking to interact with her. Within her restricted home range, she spent most time at Battery Point, particularly at a buoy in front of which she spent hours swimming in a simple pattern or logging (which was interpreted as mainly resting behavior). At Battery Point, there is a freshwater outflow in front of which Dave also spent a lot of time.

The dolphin's home range is used regularly by a variety of watercraft, including small motorboats used by fishermen. Commercial marine wildlife-watching trips do not usually operate in this area. However, small privately owned boats did run trips to observe the solitary dolphin. Larger vessels are usually much farther out to sea.

There is some leisure and commercial fishing activity conducted in this area. Recreational anglers were sometimes seen beach-casting near the dolphin, and gill nets may have been deployed within her home range too.

\section{Data Collection}

Behavioral data were collected from dedicated land-based surveys over a 6-week period from August to October 2007 between Sandgate and Hythe in Kent, Southeast England. Observations were made at locations dictated by the presence of the dolphin. Effort varied between the various survey locations with most surveys being undertaken from Battery Point in Seabrook. Seated on an elevated beach ( $\geq 3 \mathrm{~m}$ above sea level), a single observer experienced in conducting behavioral studies carried out observations during daylight hours. All observations were conducted at all tidal states in weather conditions with good visibility and Beaufort Sea States $\leq 3$. The observer used $8 \times 21$ binoculars and the naked eye.

Every behavioral event observed at the surface performed by Dave was recorded continuously with a stopwatch and approximated to the nearest second. This sampling method records all occurrences of events described in the ethogram (Table 1). These behavioral events do not represent the entire behavioral repertoire of the dolphin but only the events that could be observed at the surface. Bouts of action such as repeated breaches or tail-out dives over, for example, a 1-min period or longer were treated as many individual breaches or tail-out dives. In addition, the number of watercraft present in the area, swimmers in the water, and people watching from the beach were recorded every $30 \mathrm{~min}$.

\section{RESULTS}

Surveys were conducted on 23 days during the 6-week study period. The survey effort totaled $100 \mathrm{hr}$ of which $94 \mathrm{hr} 59$ min were spent collecting behavioral data. Survey effort differed between the five sites with (a) $83 \mathrm{hr} 50 \mathrm{~min}$ at Battery Point, (b) $13 \mathrm{hr} 30 \mathrm{~min}$ at Hythe Imperial Hotel, (c) $1 \mathrm{hr} 10 \mathrm{~min}$ at Sandgate, (d) $1 \mathrm{hr}$ at Hythe Fishermen's Beach, and (e) 30 min at Hythe Sailing Club.

The solitary bottlenose dolphin was accompanied by humans in 18.4\% (16 hr $58 \mathrm{~min}$ ) of behavioral samples, by boats in $11.3 \%$ (10 hr $24 \mathrm{~min}$ ), and by other animals: a harbor seal (Phoca vitulina) and a 
razorbill (Alca torda) in $0.49 \%$ (27 $\mathrm{min}$ ) of behavioral samples. Dave spent $8.71 \%$ ( $8 \mathrm{hr}, 2 \mathrm{~min}$ ) of this time interacting with inanimate objects (buoys, plastic bottle, outflow); she spent $61.10 \%$ (56 hr $21 \mathrm{~min}$ ) by herself.

TABLE 1. Definition of Behavioral Events (Adapted From Müller et al., 1998, and Lusseau, 2006)

\begin{tabular}{|c|c|c|}
\hline Event & Code & Definition \\
\hline Away & AWAY & $\begin{array}{l}\text { Dolphin swims away from the beach (and therefore from the observer), a swimmer, boat, } \\
\text { or inanimate object }\end{array}$ \\
\hline Belly & BELLY & Dolphin swims belly up \\
\hline Bow riding & BOW & Dolphin rides the bow wave of a boat \\
\hline Bubble blow & BB & Dolphin exhales under water, producing a stream of bubbles \\
\hline Carry & CAR & Dolphin carries or plays with an item or fish \\
\hline Change of direction & CD & Dolphin changes direction of swimming by more than 45 I and less than $180^{\circ}$ \\
\hline Chasing fish & CHAS & Dolphin chases fish with the fish clearly jumping out of the water \\
\hline Crash & CRASH & Dolphin breaches onto a swimmer, boat, or inanimate object \\
\hline Dive & $\mathrm{D}$ & Dolphin stays under water for a certain time \\
\hline Feeding & FED & Dolphin feeds \\
\hline Fish throwing & FISH THROW & Dolphin catches a fish and throws it repeatedly out of the water \\
\hline Follow & FOL & Dolphin follows boat or swimmer \\
\hline Full breach & FBR & $\begin{array}{l}\text { Dolphin jumps completely out of the water and lets himself or herself fall back into the } \\
\text { water on its side or back }\end{array}$ \\
\hline Half breach & HBR & $\begin{array}{l}\text { Dolphin jumps partly out of the water (tail fluke still submerged) and lets himself or herself } \\
\text { fall back into the water on side or back }\end{array}$ \\
\hline Head butt & $\mathrm{HB}$ & Dolphin hits a swimmer or object with head \\
\hline Head slap & HSL & Dolphin hits the water with head \\
\hline Head stand & HST & Dolphin dives vertically with tail fluke vertically out of the water for more than $3 \mathrm{~s}$ \\
\hline Head up & HUP & Dolphin swims or logs with head above the water surface \\
\hline Jump & JUMP & $\begin{array}{l}\text { Dolphin leaves the water vertically, clears entire body out of the water, and reenters the } \\
\text { water headfirst in a vertical position }\end{array}$ \\
\hline Logging & LOG & Dolphin floats at the surface \\
\hline Lunge & LUN & Dolphin suddenly rushes forward \\
\hline Push & PS & Dolphin pushes swimmer, boat, inanimate object, or animal \\
\hline Rolling over & ROLL & Dolphin rolls horizontally over in the water \\
\hline Rubbing & RUB & Dolphin rubs against a swimmer, boat, or inanimate object \\
\hline Shark & SHK & Dolphin swims just below the surface; only dorsal fin is showing \\
\hline Side & SIDE & Dolphin swims or floats on side \\
\hline Spy hop & SPY & Dolphin stands vertically in the water with body partially out of the water \\
\hline Stay & STAY & Dolphin remains close to swimmer, boat, or inanimate object \\
\hline Swimming slowly & SLOW & Dolphin swims at slow speed \\
\hline Swimming moderately & MOD & Dolphin swims at moderate speed \\
\hline Swimming fast & FAST & Dolphin swims fast (porpoising) \\
\hline Tail-out dive & TOD & $\begin{array}{l}\text { While surfacing, the dolphin arches back and increases angle of reentrance. The tail is } \\
\text { lifted out of the water and dolphin dives vertically }\end{array}$ \\
\hline Tail slap & TSL & Dolphin hits the water with fluke \\
\hline Tail-stock dive & TSD & $\begin{array}{l}\text { While surfacing, the dolphin arches back and increases angle of reentrance. Only the tail } \\
\text { peduncle is lifted out of the water, not the whole tail fluke. }\end{array}$ \\
\hline Tail up & TUP & Dolphin swims or logs at the surface with the tail out of the water \\
\hline Thrash & THR & Dolphin moves very fast in one place under water, splashing \\
\hline Towing & TOW & Dolphin tows swimmer who is holding onto dorsal fin \\
\hline Wake riding & WAKE & Dolphin rides in the wake of a boat \\
\hline
\end{tabular}


TABLE 2. Frequency (Number of Times Observed) of Behavioral Events

\begin{tabular}{|c|c|c|c|c|c|}
\hline Event Code & By Herself & With Humans & With Boats & With Inanimate Objects & With Animals \\
\hline AWAY & 153 & 1 & 1 & 1 & 0 \\
\hline BELLY & 65 & 54 & 0 & 0 & 0 \\
\hline BOW & --- & --- & 62 & 0 & 0 \\
\hline BB & 44 & 10 & 0 & 0 & 0 \\
\hline CAR & 38 & 1 & 0 & 1 & 0 \\
\hline$C D$ & 113 & 1 & 0 & 0 & 0 \\
\hline CHAS & 2 & 0 & 0 & 0 & 1 \\
\hline CRASH & --- & 6 & 0 & 0 & 0 \\
\hline D & 340 & 158 & 23 & 22 & 7 \\
\hline FED & 22 & 0 & 0 & 0 & 0 \\
\hline FISH THROW & 35 & 0 & 0 & 0 & 0 \\
\hline FOL & --- & 4 & 10 & 0 & 0 \\
\hline FBR & 8 & 0 & 1 & 0 & 0 \\
\hline HBR & 33 & 7 & 0 & 1 & 1 \\
\hline $\mathrm{HB}$ & 0 & 90 & 1 & 1 & 0 \\
\hline $\mathrm{HSL}$ & 5 & 10 & 1 & 1 & 0 \\
\hline HST & 6 & 1 & 0 & 0 & 0 \\
\hline HUP & 81 & 13 & 4 & 20 & 1 \\
\hline JUMP & 57 & 3 & 3 & 0 & 1 \\
\hline LOG & 93 & 410 & 17 & 26 & 1 \\
\hline LUN & 54 & 1 & 3 & 2 & 5 \\
\hline PS & --- & 39 & 2 & 0 & 0 \\
\hline ROLL & 41 & 7 & 0 & 1 & 0 \\
\hline RUB & --- & 3 & 2 & 4 & 0 \\
\hline SHK & 17 & 8 & 2 & 6 & 0 \\
\hline SIDE & 38 & 29 & 0 & 3 & 0 \\
\hline SPY & 13 & 4 & 2 & 1 & 0 \\
\hline STAY & --- & 24 & 14 & 0 & 0 \\
\hline SLOW & 1,494 & 253 & 140 & 138 & 11 \\
\hline MOD & 34 & 4 & 1 & 5 & 1 \\
\hline FAST & 140 & 6 & 28 & 0 & 7 \\
\hline TOD & 70 & 5 & 1 & 21 & 0 \\
\hline TSL & 89 & 25 & 0 & 6 & 0 \\
\hline TSD & 113 & 12 & 1 & 13 & 0 \\
\hline TUP & 2 & 3 & 0 & 0 & 0 \\
\hline THR & 62 & 0 & 0 & 0 & 0 \\
\hline TOW & --- & 2 & 0 & 0 & 0 \\
\hline WAKE & --- & --- & 29 & 0 & 0 \\
\hline
\end{tabular}

Thirty-eight different behaviors were identified (Table 1). Table 2 shows frequencies of different behavior events when Dave was by herself, accompanied by humans, boats, inanimate objects, or other animals. It is apparent that Dave spent less time diving when humans or boats were in her vicinity; frequencies of tail-stock dives, tail-out dives, and normal dives were much higher when she was by herself. Table 2 also shows that Dave never fed when people or boats were within her home range. She only fed or was observed throwing fish when she was by herself. The frequency of slow swimming was reduced when 
she was not by herself, whereas the frequency of the logging behavior was increased when people were in the water.

\section{Human Behavior}

Observed human behaviors included swimmers chasing Dave; grabbing at, or hanging from, her pectoral and dorsal fins; touching sensitive areas: her head, blowhole, and genitals; trying to be towed along by her; or even attempting to ride her by straddling her back. Parents also put their children on Dave's back. Dave often appeared to become more active and occasionally aggressive during such encounters.

Numbers of swimmers in the water near Dave (within $0 \mathrm{~m}$ to $3 \mathrm{~m}$ of her) ranged from 1 to 40 at the same time, whereas onlookers from the beach (stretched out over 50-100 m along the beach) ranged from 1 up to approximately 700 at peak times.

Dave also appeared to favor those people (spent more time with them) who swam farther offshore. She swam or logged next to them, dived around them, and sometimes gently pushed them with her rostrum. She has been seen to repeatedly swim in front of swimmers to intercept their course toward the beach 20 to $30 \mathrm{~m}$ from the beach. She also liked to come up underneath swimmers who were floating on their backs and push their legs into the air.

Similarly, Dave's interactions with kayaks were seen to be relatively vigorous and forceful during this study, with the dolphin regularly pushing these craft and even half-breaching on top of them (emerging partly out of the water and placing her head and upper body onto the kayak's prow, seriously upsetting its stability). Numbers of kayaks surrounding Dave ranged from 0 to 12.

\section{DISCUSSION}

\section{Behavior and Management}

The behavior reported here broadly agrees with reports of behavior of other solitary dolphins (De $O$ Santos, 1997; Dudzinski, Frohoff, \& Crane, 1995; Lockyer, 1978; Simmonds \& Stansfield, 2007; Wilke et al., 2005) and basic behavioral patterns observed and described in gregarious dolphins both in the wild and in captivity (Lusseau, 2006; Müller, Boutière, Weaver, \& Candelon, 1998; Shane, 1990). It is of interest that Dave's behavior changed significantly when people were in the water with her. In particular, at such times there was no clear feeding behavior; in addition, her diving activity changed, which could also be interpreted as a lessening of foraging activity.

Resting behavior was also seemingly reduced, although this is less easy to interpret. Resting behavior probably consisted predominantly of swimming slowly (mainly seen around a particular buoy at Battery Point) but might include logging behavior; this was strongly exhibited when people were in the water. In these instances, however, this stationary activity may have been part of Dave's effort to socialize with people, noting the relatively poor swimming skills of the latter. Bloom (1997) noticed that the resting behavior of the solitary sociable dolphin Freddy, who used to rest next to one particular buoy, was rarely observed during summer when many human-dolphin interactions took place; however, it much increased during winter when interactions with humans were less common.

Behavior is often one of the only available indicators of the condition of marine mammals and is a necessary component in the evaluation of their welfare (Frohoff, 2000). The alteration of one or more aspects of the behavioral repertoire could result in compromised well being. Resting and feeding are the two behaviors crucial to the well being of any animal and should not be disrupted (Goodwin \& Dodds, 
2008). Should this happen, it is likely that the fitness of the animal will deteriorate, placing the animal at greater risk.

Some of Dave's behaviors at times appeared hazardous to the people in the water with her. She was observed to breach on top of several people (a behavior not reported before this study began); this behavior may be a component in the dolphin becoming more dominant in interactions. On one occasion during the study period, she was seen stopping a young swimmer leaving the water and was reported to have behaved in the same way on earlier occasions. Similar behavior from another UK solitary dolphin was reported and has been interpreted by observers as a result of the dolphins' desire to continue with their interactions (Simmonds \& Stansfield, 2007).

Neither people who had been breached on nor those stopped from leaving the water complained. Still, the risk from these behaviors to those in the water with Dave seems high, especially in light of a Florida snorkeler injured in 1995 by the solitary female dolphin Pita (Dudzinski et al., 1995). In addition, 29 bathers in Brazil suffered minor injuries, and a male bather died from injuries caused by the solitary sociable dolphin Tião (De O Santos, 1997). We should note, however, that Tião reacted aggressively only when repeatedly harassed and after some bathers had placed ice-cream sticks into his blowhole (De O Santos, 1997).

Generally, robust, boisterous, or sexual behavior from a dolphin may lead to inappropriate behavior from people in return. An anthropomorphic interpretation of behavior (perhaps egged on by the media) or a fundamental lack of information on the natural needs of dolphins in the wild may also affect this (Wilke et al., 2005). People wishing to fulfill a desire to engage in an encounter with a dolphin may not consider the animal's needs and might, either accidentally or intentionally, harass or harm the dolphin. They might touch sensitive parts of the animal's body or react forcefully to the dolphin's behavior, injuring the dolphin in the process. Most of the time, it is almost impossible to tell who evoked a response first, the human or the dolphin.

Several concerned nongovernmental organizations (NGOs), working with a team of local volunteers, responded to Dave's presence by establishing regular beach patrols to help monitor the dolphin and also to talk to the visiting public. These volunteers also put up posters advising people of the risk to the swimmers and to the dolphin. Some members of the public saw such actions as inappropriate, and posters were regularly torn down. The police were also involved in trying to protect the dolphin. They were called in on several occasions when the safety of the dolphin seemed compromised. On one of these occasions, the police arrested two inebriated men who were in the water with the dolphin.

The coalition of UK NGOs that had been trying to manage Dave's situation wrote to the Kent Tourist Board in February 2007 to warn of the threats to both the dolphin and her admirers. In March, a mailing to all schools in the Folkestone area was followed by a public meeting held in Folkestone, to which members of the local council and the relevant agencies were invited. In June 2007, the coalition wrote to the Chamber of Commerce and had a meeting with the police and other safety agencies to further explore the issues relating to Dave's residency. In July 2007, the network wrote to the local Member of Parliament, putting forward their concern for the dolphin's and the people's safety. On October 19, the network had another meeting with the police and other safety agencies to again explore the issues relating to Dave's residency.

Home Range

Compared with observed home ranges of wild bottlenose dolphin individuals and groups, Dave's observed home range seemed very small. Irvine, Scott, Wells, and Kaufmann (1979) reported a mean 
home range of $85 \mathrm{~km}^{2}$ for a group of bottlenose dolphins in the western North Atlantic. Odell and Asper (1990) found linear home ranges of dolphin groups in Florida to vary between $1.8 \mathrm{~km}$ and $100 \mathrm{~km}$, whereas Balance (1992) found home ranges for individual dolphins of up to $65 \mathrm{~km}$ in the Gulf of California. However, as a common feature of sociable bottlenose dolphins, Lockyer (1978) noted a limited home range, often only a few bays and harbors.

Some solitary dolphins seem to move between "nodal home ranges." They concentrate their behavior around a series of geographically separated nodes, staying in small areas for several years before starting longer excursions and travels outside their home ranges (Lockyer, 1978; Shane, Wells, \& Würsig, 1986; Wells et al., 1990). The reasons for the small extent of home ranges of solitaries are not clear, but these areas obviously have significance for these animals.

Dave's small inshore home range meant that she was easily accessible to humans wishing to interact with her. They could either swim out to her or take a boat or kayak out to see her anywhere in her home range. It has been suggested that a dolphin faced with unwanted attention would simply move away. However, it is clear from her prolonged presence in this small area that this home range was important to Dave and that she was reluctant to leave it. For her, it clearly included adequate feeding opportunities and, as shown by the authors' observations, resting grounds.

The team of volunteers who informally monitored Dave's behavior reported that her absence from her 5 $\mathrm{km}$ home range was rarely apparent. However, there was an 11-day period (September 22 to October 3, 2007) when she was absent from her usual haunts. This more widely roaming behavior could have occurred because she was becoming sexually mature and had developed an increasing need for social contact with conspecifics or because of changes in the local environment such as prey availability. Around November 7, 2007, some days after her tail was wounded, she went missing and has not been seen since.

\section{CONCLUSION}

Although this study reports only on Dave's behavior at one point in time, it is clear that her behavior changed over time. When she first arrived on the Kent coast, she did not approach or associate with swimmers or boats (A. Levine and T. Whittaker, personal communication, August 23, 2007). People swim off this coastline year-round, and some tried to associate with her from soon after her arrival. Over time, and closely in line with the stages described by Wilke et al. (2005), she became habituated by people. By the time of this study, she was attracted to them and was becoming increasingly forceful in these interactions. Both habituation and attraction are considered learned responses (Knight \& Temple, 1995).

Habituation is defined as a waning of response to a repeated or ongoing stimulus associated with neither a positive nor negative reward, resulting in the stimulus having a lack of significance to the animal (Thorpe, 1963). Attraction, however, is defined as the strengthening of a positive association with a repeated stimulus (Knight \& Temple, 1995), manifesting behaviorally as an increase in the animal's positive attention (visual, acoustic, or tactile) to a stimulus (Frohoff, 2000).

Knight and Temple (1995) demonstrated that attraction of wildlife to human activity can be harmful to both humans and wildlife. Two possible functions of habituation, desensitization and tolerance, can also be harmful to a sociable dolphin (Knight \& Temple, 1995; Richardson, Greene, Malme, \& Thomson, 1995). Desensitization is the decreasing responsiveness to a stimulus over time; tolerance manifests itself by the animal's remaining near a stimulus regardless of its negative significance to the animal (Richardson et al., 1995). These responses are possibly harmful; they may result in abnormally and inappropriately weak responses relative to the dangers that the stimuli (boat motors) present (Frohoff, 2000). In addition, there 
might be physiological effects (stress) accompanying these behavioral responses, especially when exposure to the stimuli is chronic (Richardson et al., 1995).

Desensitization and tolerance might have led to the injuries Dave received during the summer. Some injuries appeared to come from a small propeller; some even looked like knife wounds. At the time she lost a large part of her tail, she was also found to have some monofilament fishing line (and a hook) embedded in her dorsal fin (Figure 1[b,c]). The tail wound was regarded as life-threatening and treated with antibiotics administered by a veterinarian using a handheld hypodermic. It is not clear if Dave survived this wound as she went missing soon after.

Dave's situation was similar to that of another young female solitary bottlenose dolphin known as Marra, who perished in 2006 after being habituated to human contact and exhibiting similar behaviors (Simmonds \& Stansfield, 2007). The wounds exhibited by Dave and also Marra bear out the vulnerability of solitary dolphins and the welfare issues that relate to them.

As with Dave, Marra clearly received a number of superficial wounds that appeared to be caused by propeller strikes and possibly rope entanglement (L. Stansfield, personal observation, September 22, 2009). More significantly, she stranded on one occasion and would probably have perished had she not been found and swiftly refloated. Finally, the cause of her death-an opportunistic bacterial infection from a pathogen common in polluted near-shore waters, which may well have entered her body through her wounds, again underlines such concerns.

These episodes illustrate the vulnerability of solitary sociable dolphins and that such animals cannot be adequately protected in UK waters. As with other lone dolphins, explanations for Dave's solitary condition are not apparent.

\section{ACKNOWLEDGMENTS}

We thank all the British Divers Marine Life Rescue (BDMLR) volunteers who assisted on the beach. In particular, we thank Lyn Griffiths and Alex Levine from BDMLR for all their help, support, camaraderie, and laughs; Michelle Spain from BDMLR for sharing her house and cats with Sonja M. Eisfeld; Terry Whittaker for allowing us to use his pictures here and sharing his photography skills, his time, Internet, printer, and home; Christina Lockyer and Giovanni Bearzi for providing valuable literature; Vicki Brown for help with making the location maps; and two anonymous reviewers for their valued comments on the article.

\section{REFERENCES}

Balance, L. T. (1992). Habitat use patterns and ranges of the bottlenose dolphin in the Gulf of California, Mexico. Marine Mammal Science, 8, 267-276.

Bearzi, G. (1997). A "remnant" common dolphin observed in association with bottlenose dolphins in the Kvarneric (northern Adriatic Sea). European Research on Cetaceans, 10, 204.

Bloom, P. R. S. (1997). The movements and activity time budget of a wild, solitary, bottlenosed dolphin (Tursiops truncates): Monitored through complete 24 hour cycles. European Research on Cetaceans, 11, 67-71. 
Chisholm, S. (2005, December). Luna: Observations and options. In Research and management of solitary, sociable odontocetes (pp. 37-39). Workshop workbook (unpublished). Workshop convened at the 16th Biennial Conference on the Biology of Marine Mammals, San Diego, CA.

Connor, R. C., Wells, R. S., Mann, J., \& Read, A. J. (2000). The bottlenose dolphin: Social relationships in a fission-fusion society. In J. Mann, R. C. Connor, P. L. Tyack, \& H. Whitehead (Eds.), Cetacean society. Field studies of dolphins and whales (pp. 91-126). Chicago: University of Chicago Press.

De O Santos, M. C. (1997). Lone sociable bottlenose dolphin in Brazil: Human fatality and management. Marine Mammal Science, 13, 355-356.

Dudzinski, K. M., Frohoff, T. G., \& Crane, N. L. (1995). Behavior of a lone female bottlenose dolphin (Tursiops truncatus) with humans off the coast of Belize. Aquatic Mammals, 21, 149-153.

Frohoff, T. G. (2000, June). Behavioral indicators of stress in odontocetes during interactions with humans: A preliminary review and discussion. Paper SC/52/WW2 presented to the Scientific Committee of the International Whaling Commission, Adelaide, Australia.

Frohoff, T. G., \& Packard, J. M. (1995). Human interactions with free-ranging and captive bottlenose dolphins. Anthrozöos, 8, 44-53.

Frohoff, T. G., Vail, C. S., \& Bossley, M. (Eds.). (2006, December). Preliminary proceedings of the workshop on the research and management of solitary, sociable odontocetes. Convened at the 16th Biennial Conference on the Biology of Marine Mammals, San Diego, CA, December 10, 2005. Paper SC/58/13 presented to the Scientific Committee of the International Whaling Commission.

Goodwin, L., \& Dodds, M. (2008). Lone rangers: A report on solitary dolphins and whales including recommendations for their protection. Marine Connection. Retrieved April 28, 2008, from http://www.marineconnection.org/campaigns/solitary_report_details_page.htm

Hartley, D., Merigo, C., Blanchard, T. W., Dunn, J. L., Frady, T., Ketten, D., et al. (2005, December). Managing solitary beluga whales in the northeastern US: The story of "Poco." In Research and management of solitary, sociable odontocetes (pp. 32-36). Workshop workbook (unpublished). Workshop convened at the 16th Biennial Conference on the Biology of Marine Mammals, San Diego, CA.

Irvine, A. B., Scott, M. D., Wells, R. S., \& Kaufmann, J. H. (1979). Movements and activities of the Atlantic bottlenosed dolphin (Tursiops truncates). Cetology, 13, 1-5.

Kinsman, C., \& Frohoff, T. (2005, December). The whale stewardship project: Research and stewardship of solitary sociable Beluga whales in eastern Canada. In Research and management of solitary, sociable odontocetes (pp. 26-31). Workshop workbook (unpublished). Workshop convened at the 16th Biennial Conference on the Biology of Marine Mammals, San Diego, CA.

Knight, R. L., \& Temple, S. A. (1995). Origin of wildlife responses to recreationists. In R. L. Knight \& K. J. Gutzwiller (Eds.), Wildlife and recreationists: Coexistence through management and research (pp. 81-92). Washington, DC: Island Press.

Lockyer, C. (1978). The history and behavior of a solitary wild, but sociable, bottlenose dolphin (Tursiops truncatus) on the west coast of England and Wales. Journal of Natural History, 12, 513-528.

Lockyer, C. (1990). Review of incidents of wild, sociable dolphins, worldwide. In S. Leatherwood \& R. R. Reeves (Eds.), The bottlenose dolphin (pp. 337-353). San Diego, CA: Academic.

Lockyer, C., \& Morris, R. J. (1986). The history and behavior of a wild, sociable bottlenose dolphin (Tursiops truncatus) off the north coast of Cornwall. Aquatic Mammals, 12, 3-6.

Lusseau, D. (2006). Why do dolphins jump? Interpreting the behavioral repertoire of bottlenose dolphins (Tursiops sp.) in Doubtful Sound, New Zealand. Behavioral Processes, 73, 257-265.

Lusseau, D., Schneider, C., Boisseau, O. J., Haase, P., Slooten, E., \& Dawson, S. M. (2003). The bottlenose dolphin community of Doubtful Sound features a large proportion of longlasting associations. Can geographic isolation explain this unique trait? Behavioral Ecology and Sociobiology, 54, 396-405. 
Müller, M., Boutière, H., Weaver, A., \& Candelon, N. (1998). Ethogram of the bottlenose dolphin (Tursiops truncatus) with special reference to solitary and sociable dolphins. English Translation of Vie Milieu, 48, 89-104.

Odell, D. K., \& Asper, E. D. (1990). Distribution and movements of freeze-branded bottlenose dolphins in the Indian and Banana rivers, Florida. In S. Leatherwood \& R. R. Reeves (Eds.), The bottlenose dolphin (pp. 515-540), San Diego, CA: Academic.

Richardson, W. J., Greene, C. R., Malme, C. I., \& Thomson, D. H. (1995). Marine mammals and noise. San Diego, CA: Academic.

Sandstrom, D. (2005, December). Working together for Springer: The Orphan Orca Fund. In Research and management of solitary, sociable odontocetes (pp. 40-43). Workshop workbook (unpublished). Workshop convened at the 16th Biennial Conference on the Biology of Marine Mammals, San Diego, CA.

Shane, S. H. (1990). Behavior and ecology of the bottlenose dolphin at Sanibel Island Florida. In S. Leatherwood \& R. R. Reeves (Eds.), The bottlenose dolphin (pp. 245-265). San Diego, CA: Academic.

Shane, S. H., Wells, R. S., \& Würsig, B. (1986). Ecology, behavior and social organisation of the bottlenose dolphin: A review. Marine Mammal Science, 2, 34-63.

Simmonds, M., \& Stansfield, L. (2007, December). Solitary sociable dolphins in the UK. British Wildlife, 19, 96-101.

Smolker, R. A., Richards, A. F., Connor, R. C., \& Pepper, J. W. (1992). Sex differences in patterns of associations among Indian Ocean bottlenose dolphins. Behavior, 123, 38-69.

Thorpe, W. H. (1963). Learning and instinct in animals. London: Methuen.

Wells, R. S., Hansen, L. J., Baldridge, A., Dohl, T. P., Kelly, D. L., \& Defran, R. H. (1990).Northward extension of the range of bottlenose dolphins along the California coast. In S. Leatherwood \& $R$. R. Reeves (Eds.), The bottlenose dolphin (pp. 421-431), San Diego, CA: Academic.

Wilke, M., Bossley, M., \& Doak, W. (2005). Managing human interactions with solitary dolphins. Aquatic Mammals, 31, 427-433.

Würsig, B., \& Würsig, M. (1977). The photographic determination of group size, composition and stability of coastal porpoises (Tursiops truncatus). Science, 198, 755-756. 